\title{
Dental caries experience and salivary streptococcus mutans, lactobacilli scores, salivary flow rate and salivary buffreing capacity among 6 year old Indian school children.
}

\author{
B. Sakeenabi ${ }^{1}$, SS. Hiremath ${ }^{2}$ \\ ${ }^{1}$ MDS, Reader, Department of Preventive and Community Dentistry, College of Dental Sciences, Davangere, Karnataka, India. \\ ${ }^{2} \mathrm{MDS}$, Dean cum Director, Government dental college and research Institute, Fort, Bangalore.
}

Correspondence:

Department of Community Dentistry,

College of Dental sciences,

Davangere, Karnataka, India, 577004.

E-mail addres:drsaki@sify.com

Received: $24 / 09 / 2010$

Accepted: $28 / 02 / 2011$

\begin{abstract}
Sakeenabi B, Hiremath SS. Dental caries experience and salivary streptococcus mutans, lactobacilli scores, salivary flow rate and salivary buffreing capacity among 6 year old Indian school children. J Clin Exp Dent. 2011;3(5):e412-7

http://www.medicinaoral.com/odo/volumenes/v3i5/jcedv3i5p412.pdf
\end{abstract}

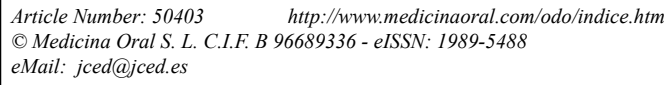

\begin{abstract}
Objectives: The aim of this study was to assess the possible relationship between salivary cariogenic microflora, buffer capacity, secretion rate and caries experience among 6 -year- old school going children in Davangere city, Karnataka, India.

Study design: A total of 196, 6 year old school children were selected by a two- stage random sampling method. Parents were interviewed regarding sociodemographic details. Clinical examination of children was conducted to assess dental caries experience and stimulated saliva was collected to assess S.mutans levels, lactobacilli, salivary flow and buffering capacity of saliva. Difference in proportions was tested using Pearson $\square 2$ test, and also analysis of variance (ANOVA) was used to evaluate difference between the groups. Dental caries experience was correlated with salivary factors using Spearman's correlation coefficient.

Results: Out of 196 children, 96 were boys and 100 were girls. Overall 97 (49.49\%) children were caries free ( $\mathrm{dmft}$, DMFT $=0)$ and $99(50.51 \%)$ children presented with caries (dmft, DMFT $>0)$, out of which $42(42.42 \%)$ were boys and $57(57.58 \%)$ were girls and there was no significant diffrence between two groups $(p=0.086$, two sided). The mean $\mathrm{dmft}$ and $\mathrm{dmfs}$ score for the overall group was 3.20 and 5.43 respectively. The mean DMFT and DMFS score was 0.23 and 0.25 respectively. Statistically significant difference (Independent sample t- test) $(\mathrm{p}<0.05)$ was found between mean $\mathrm{ft}$ and mean $\mathrm{fs}$ scores between sexes. A highly significant correlation was seen between the mean caries score and salivary variables.

Conclusion: To conclude, high levels of salivary microbiological counts in correlation with the caries data stress the importance of these factors and urge the necessity of elective preventive programs in this region.
\end{abstract}

Key Words: dental caries experience, streptococcus mutans(S.mutans), lactobacillus, salivary flow, salivary buffering capacity, Colony Forming Unit(CFU). 


\section{Introduction}

Dental caries is a localized and transmissible pathological infectious process that results in destruction of hard dental tissues (1). It is the main oral health problem in both industrialized and increasing in developing countries and it affects $60-90 \%$ of school aged children and adults (2). In India, children comprise $40 \%$ of a rapidly growing population. The prevalence of dental caries varies from $33.7 \%-90 \%$ in children population and is increasing at an alarming rate (3-4). A variety of potential predictors has been examined for association with caries increments in longitudinal and cross sectional studies, including initial, or baseline caries prevalence scores for permanent and primary teeth, characteristics of occlusal morphology, levels of S.mutans and lactobacillus, salivary buffering capacity, dietary factors, sex, race , and socio-economic status (3,5-12).

The importance of, S.mutans, lactobacilli and saliva in the development of dental caries has been reviewed extensively through many cross- sectional studies $(3,5-8)$. The studies have shown that the subjects with active caries tend to harbor higher number of mutans streptococci and lactobacilli in their saliva and plaque than those who are caries free. Moreover, longitudinal studies have demonstrated that there is an increase overtime in the number of S.mutans and lactobacilli associated with onset and progression of caries (9-13).

Many attempts have been made recently to identify those children who are more susceptible to caries development so as to implement specific prevention programmes for them.

This study is the part of ongoing longitudinal study, in this part, we have tried to evaluate the possible relationship between salivary cariogenic microflora, buffer capacity, secretion rate and caries experience among 6 year old school going children in Davangere city, Karnataka, India. More specifically, (I) Is there an association between caries experience and different levels of S.mutans in saliva (II) Is there an association between caries experience and different levels of lactobacilli in saliva (III) Is there an association between caries experience and buffering capacity of saliva (IV) Is there an association between caries experience and salivary flow rates.

\section{Materials and Methods}

Davangere is the district headquarter of Davangere district, divided into North and South zones. Total number of public schools was 61 and private schools 105 (20072008 data). Approximately $10 \%$ of schools (6 public and 10 private schools) were selected by lottery method to meet the sample size of 196. Two stages random sampling method was followed with school as primary sampling unit and individual child the unit of enquiry. Children were selected proportionate to the number of children in each school by systematic random sampling.
All required and relevant information about the number and location of schools in Davangere city was obtained from the office of Deputy Director of Public Instruction, Davangere. Ethical clearance was taken from the ethical committee of Government dental College, Bangalore City, India. Necessary permission was taken from school authorities and the written informed consent was taken from the parents before the start of the study. Inclusion criteria were as follows: (I) Children who were permanent residents of Davangere City. (II) Children with informed consent from the parent/ -guardian. Exclusion criteria were as follows: (I) Children who were severely ill. (II) Children having difficulty in opening the mouth. (III) Children who had taken antibiotics in the last month. (IV) Children with orthodontic appliances.

The study was carried out using a specific pretested proforma, which consisted of two parts. First part consisted of general information of school children regarding age and sex and the second part consisted of clinical oral examination. The oral examination of school children was carried out under natural light using plane mouth mirrors, and World Health Organization (WHO) probes. The sterilization of instruments was done by autoclaving. No radiographs were used. The same examiner examined all children. The intra examiner calibration was performed with respect to the diagnostic criteria of caries. A significant correlation was found with a kappa value of $0.96, p<0.05$ for dental caries. Caries status was determined by DMFS, DMFT, dmft and dmfs using WHO criteria (14).

Salivary analysis:

Stimulated saliva was collected from each subjects and microbiological assay and salivary tests commenced within 24 hours of saliva collection.

Method of saliva collection: Saliva collection was scheduled after the clinical examination. Two students at a time were made to sit comfortably on the chair. Children were made to swallow the preexisting saliva, in order to clear the mouth of any residual unstimulated saliva. After this each student was asked to chew a standard piece of paraffin wax, for $5 \mathrm{~min}$ and the stimulated saliva was collected. The saliva samples of all the participants were identified by a code number during the period of sample collection and processing.

Salivary flow rate: once the participants could chew comfortably on the wax, he/she was asked to expectorate all saliva formed over a $5 \mathrm{~min}$ period into the graduated sterile cylinder. After the disappearance of the salivary froth, the secretion rate was estimated in milliliters per $\min$.

Salivary secretion rate were then scored as follows:- 0 $=>0.7 \mathrm{ml} / \mathrm{min}, 1=0.3-0.7 \mathrm{ml} / \mathrm{min}, 2=<0.3 \mathrm{ml}$ $/ \min$

Buffering capacity of saliva: To estimate buffering capacity, three $\mathrm{ml}$ of $0.005 \mathrm{~mol} / 1 \mathrm{HCL}$ solution were added to 
$1 \mathrm{ml}$ of saliva. The sample was shaken and the stopper was then removed to eliminate carbon dioxide. The sample was allowed to stand for ten minutes and the final $\mathrm{pH}$ was measured with commercially purchased Hindicorm $\mathrm{pH}$ paper (Himedia,Bombay,India), which had a predetermined $\mathrm{pH}$ range and categorized accordingly $(\mathrm{pH}$ range 3.5-6, 6.5-9).

Salivary buffering capacity were then scored as follows: $0-\mathrm{pH}>6.0,1-\mathrm{pH} 4.5-5.5,2-\mathrm{pH}<4.0$

Microbiological Procedure: The sample was transported to the laboratory immediately after collection using thioglycollate broth and processed on same day. The sample was vortexed $(15 \mathrm{sec}$,$) and diluted 1:1000 in isotonic$ saline solution prior to inoculation. One loop $\left(1 / 1000^{\text {th }}\right.$ $\mathrm{ml}$ of sample) was inoculated on the Mitis Salivarius agar with potassium tellurite medium, bacitracin and $20 \%$ sucrose .The plates were incubated at $37^{\circ} \mathrm{C}$ anaerobically. For lactobacilli one loop of the diluted sample was inoculated on Rogosa SL agar plates and incubated aerobically for $72 \mathrm{~h}$. After $72 \mathrm{~h}$ colony characteristics were studied and the number of colony- forming units of S.mutans $(\mathrm{CFU} / \mathrm{ml})$ and lactobacilli $(\mathrm{CFU} / \mathrm{ml})$ of saliva was determined using a colony counter.

Statistical analysis: The Statistical Package for Social Science (SPSS INC Chicago link), version 17 was used for analysis. Difference in proportions was tested using Kruskal-Wallis ANOVA followed by Mann-Whitney U test for intra group comparison, and difference in means was tested using ANOVA followed by Tukey's post hoc and Independent sample t-test as necessary. Dental caries experience was correlated with salivary factors using Spearman's correlation coefficient. Level of statistical significance was assumed at $\mathrm{p}<0.05$.

\section{Results}

Caries prevalence: Total number of study participants were 196 out of which 96 (48.98\%) were boys and 100 $(51.02 \%)$ were girls. Overall 97 (49.49\%) children were caries free $(\mathrm{dft}, \mathrm{DMFT}=0)$ and $99(50.51 \%)$ children presented with caries (dft, DMFT $>0$ ), out of which 42 $(42.42 \%)$ were boys and $57(57.58 \%)$ were girls and there was no significant difference between two groups ( $\mathrm{p}$ $=0.086$, two sided). The mean dmft and dmfs score for overall group was 3.20 and 5.43 respectively. The mean DMFT and DMFS score was 0.23 and 0.25 respectively. Statistically significant difference (Independent sample $t$ - test $)(\mathrm{p}<0.05)$ was found between mean $\mathrm{ft}$ and mean fs scores between sexes.

Salivary secretion rates: It was between $0.4-1.5 \mathrm{ml} / \mathrm{min}$ in the examined sample with a mean flow rate of 0.96 $\pm 0.23 \mathrm{ml} / \mathrm{min}$. Majority $(89.29 \%)$ of study participants presented with salivary flow rate score $0(>0.7 \mathrm{ml} / \mathrm{min})$, (Table 1).

Salivary buffering capacity: The analysis of the buffer capacity of saliva showed that the majority $(75 \%)$ of participants presented with buffer capacity of $>6 \mathrm{pH}$, followed by $23.47 \%$ with buffer score of $1(\mathrm{pH} 4.5-5.5)$ and $1.53 \%$ with buffer score of $2(\mathrm{pH}<4.5)$ (Table 1$)$.

Salivary S.mutans: A total of $98.47 \%$ carried detectable salivary levels of S.mutans and $46.94 \%$ of these belonged to S.mutans score $2\left(10^{4}-10^{5} \mathrm{CFU} / \mathrm{ml}\right)$ and $29.59 \%$ with score $3\left(>10^{5} \mathrm{CFU} / \mathrm{ml}\right)$ (Table 1).

Salivary lactobacilli: A total of $87.24 \%$ carried detectable salivary levels of lactobacilli and $37.75 \%$ of these belonged to score $2\left(10^{5} \mathrm{CFU} / \mathrm{ml}\right)$ and $34.18 \%$ with score $1\left(10^{4} \mathrm{CFU} / \mathrm{ml}\right)$ (Table 1$)$

Caries status according to salivary variables: 78 $(78.79 \%)$ children with caries had normal salivary flow rate $(0=>0.7 \mathrm{ml} / \mathrm{min})$. 51 children $(51.51 \%)$ with caries belongs to salivary buffering capacity of $\mathrm{pH}>6$ and $98.97 \%$ of caries free children belongs to buffer capacity of $\mathrm{pH}>6$, the difference between the groups was statistically significant. Majority $(49.49 \%)$ of children with caries presented with lactobacilli score 2, compared to $25.77 \%$ of caries free children presented with lactobacilli score 2 and the difference between the groups was sta-

\begin{tabular}{|c|c|c|c|c|c|c|c|c|c|c|c|c|c|}
\hline \multirow[t]{2}{*}{ Sex } & \multicolumn{2}{|c|}{$\begin{array}{l}\text { Salivary flow } \\
\text { rate (ml/min) }\end{array}$} & \multicolumn{3}{|c|}{$\begin{array}{l}\text { Salivary buffering } \\
\text { capacity }(\mathrm{pH})\end{array}$} & \multicolumn{4}{|c|}{$\begin{array}{l}\text { Salivary S.mutans level } \\
\text { (CFU/ml) }\end{array}$} & \multicolumn{4}{|c|}{$\begin{array}{l}\text { Salivary lactobacilli level } \\
\text { (CFU/ml) }\end{array}$} \\
\hline & $\begin{array}{l}0 \\
(>0.7)\end{array}$ & $\begin{array}{l}1 \\
(0.3-0.7)\end{array}$ & $\begin{array}{l}0 \\
(>6)\end{array}$ & $\begin{array}{l}1 \\
(4.5-5.5)\end{array}$ & \begin{tabular}{|l|l|}
2 \\
$(<4)$
\end{tabular} & \begin{tabular}{|l|}
0 \\
(negli- \\
gible)
\end{tabular} & $\begin{array}{l}1 \\
\left(<10^{4}\right)\end{array}$ & \begin{tabular}{|l|} 
\\
$\left(10^{4}-10^{5}\right)$
\end{tabular} & $\begin{array}{l}3 \\
\left(>10^{5}\right)\end{array}$ & $\begin{array}{l}0 \\
\left(<10^{3}\right)\end{array}$ & $\begin{array}{l}1 \\
\left(10^{4}\right)\end{array}$ & $\begin{array}{l}2 \\
\left(10^{5}\right)\end{array}$ & \begin{tabular}{|l|}
3 \\
$\left(\geq 10^{6}\right.$
\end{tabular} \\
\hline $\begin{array}{l}\text { Boys (n) } \\
\%\end{array}$ & $\begin{array}{l}86 \\
89.58\end{array}$ & 10.42 & 77.08 & $\begin{array}{l}21 \\
21.87\end{array}$ & \begin{tabular}{|l|}
1 \\
1.04 \\
\end{tabular} & \begin{tabular}{|l|}
1 \\
1.04
\end{tabular} & $\begin{array}{l}24 \\
25\end{array}$ & 40.90 & & 15.62 & \begin{tabular}{|l|}
35 \\
36.46
\end{tabular} & $\begin{array}{l}34 \\
31.42\end{array}$ & \begin{tabular}{|l|}
12 \\
12.5
\end{tabular} \\
\hline $\begin{array}{l}\text { Girls (n) } \\
\%\end{array}$ & $\begin{array}{l}89 \\
89 \\
\end{array}$ & $\begin{array}{l}11 \\
11 \\
\end{array}$ & $\begin{array}{l}73 \\
73 \\
\end{array}$ & $\begin{array}{l}25 \\
25\end{array}$ & 2 & $\begin{array}{l}2 \\
2 \\
\end{array}$ & $\begin{array}{l}19 \\
19 \\
\end{array}$ & $\begin{array}{l}45 \\
45 \\
\end{array}$ & & $\begin{array}{l}10 \\
10 \\
\end{array}$ & $\begin{array}{l}32 \\
32 \\
\end{array}$ & $\begin{array}{l}40 \\
40\end{array}$ & $\begin{array}{l}18 \\
18 \\
\end{array}$ \\
\hline $\begin{array}{l}\text { Total }(\mathrm{n}) \\
\%\end{array}$ & $\begin{array}{l}175 \\
89.29\end{array}$ & $\begin{array}{l}21 \\
10.71\end{array}$ & $\begin{array}{l}147 \\
75\end{array}$ & $\begin{array}{l}46 \\
23.47\end{array}$ & $\begin{array}{l}3 \\
1.53\end{array}$ & $\begin{array}{l}3 \\
1.53\end{array}$ & $\begin{array}{l}43 \\
21.94\end{array}$ & $\begin{array}{l}92 \\
46.94\end{array}$ & $\begin{array}{l}58 \\
29.59\end{array}$ & $\begin{array}{l}25 \\
12.75\end{array}$ & $\begin{array}{l}67 \\
34.18\end{array}$ & $\begin{array}{l}74 \\
37.75\end{array}$ & $\begin{array}{l}30 \\
15.31\end{array}$ \\
\hline
\end{tabular}

Boys: number of individuals divided by the total number, 96

Girls: number of individuals divided by the total number, 100

Total: number of individuals divided by the total number, 196 


\begin{tabular}{|c|c|c|c|c|c|c|c|c|c|c|c|c|c|}
\hline \multirow[t]{2}{*}{\begin{tabular}{|l|} 
Caries \\
status
\end{tabular}} & \multicolumn{2}{|c|}{$\begin{array}{l}\text { Salivary flow } \\
\text { rate }(\mathrm{ml} / \mathrm{min})\end{array}$} & \multicolumn{3}{|c|}{$\begin{array}{l}\text { Salivary buffering } \\
\text { capacity }(\mathrm{pH})\end{array}$} & \multicolumn{4}{|c|}{$\begin{array}{l}\text { Salivary S.mutans level } \\
\text { (CFU/ml) }\end{array}$} & \multicolumn{4}{|c|}{$\begin{array}{l}\text { Salivary lactobacilli level } \\
\text { (CFU/ml) }\end{array}$} \\
\hline & $\begin{array}{l}0 \\
(>0.7)\end{array}$ & \begin{tabular}{|l|}
1 \\
$(0.3-0.7)$
\end{tabular} & $\begin{array}{l}0 \\
(>6)\end{array}$ & \begin{tabular}{|l|}
1 \\
$(4.5-5.5)$
\end{tabular} & \begin{tabular}{|l|l}
2 \\
$(<4)$
\end{tabular} & $\begin{array}{l}0 \\
\text { (negli- } \\
\text { gible) }\end{array}$ & $\begin{array}{l}1 \\
\left(<10^{4}\right)\end{array}$ & \begin{tabular}{|l}
2 \\
$\left(10^{4}\right.$ \\
$\left.-10^{5}\right)$
\end{tabular} & $\begin{array}{l}3 \\
\left(>10^{5}\right)\end{array}$ & $\begin{array}{l}0 \\
\left(<10^{3}\right)\end{array}$ & $\begin{array}{l}1 \\
\left(10^{4}\right)\end{array}$ & $\begin{array}{l}2 \\
\left(10^{5}\right)\end{array}$ & $\begin{array}{l}3 \\
\left(>10^{6}\right)\end{array}$ \\
\hline \begin{tabular}{|c|}
$\mathrm{n}^{\mathrm{a}}$ \\
$\%$ \\
\end{tabular} & \begin{tabular}{|l|}
97 \\
100 \\
\end{tabular} & 0 & \begin{tabular}{|l|}
96 \\
98.97 \\
\end{tabular} & $\begin{array}{ll}1 \\
1.03 \\
\end{array}$ & 0 & \begin{tabular}{|l|}
2 \\
2.06 \\
\end{tabular} & \begin{tabular}{|l|}
37 \\
38.14 \\
\end{tabular} & $\begin{array}{ll}48 \\
49.48 \\
\end{array}$ & \begin{tabular}{|l|}
10 \\
10.31 \\
\end{tabular} & \begin{tabular}{|l|}
20 \\
20.62 \\
\end{tabular} & \begin{tabular}{|l|}
49 \\
50.51 \\
\end{tabular} & \begin{tabular}{|l|}
25 \\
25.77 \\
\end{tabular} & \begin{tabular}{|l|}
3 \\
3.09 \\
\end{tabular} \\
\hline $\begin{array}{l}\mathrm{n}^{\mathrm{b}} \\
\% \\
\end{array}$ & $\begin{array}{ll}78 \\
78.79 \\
\end{array}$ & \begin{tabular}{|l|}
21 \\
21.21
\end{tabular} & $\begin{array}{ll}51 \\
51.51 \\
\end{array}$ & \begin{tabular}{|l|}
45 \\
45.45 \\
\end{tabular} & \begin{tabular}{|l|}
3 \\
3.03 \\
\end{tabular} & \begin{tabular}{|l|}
1 \\
1.01 \\
\end{tabular} & \begin{tabular}{|l|}
6 \\
6.06 \\
\end{tabular} & \begin{tabular}{|l|}
44 \\
44.44 \\
\end{tabular} & \begin{tabular}{|l|}
48 \\
48.48 \\
\end{tabular} & \begin{tabular}{|l|}
5 \\
5.05 \\
\end{tabular} & \begin{tabular}{|l|l|}
18 \\
18.18 \\
\end{tabular} & \begin{tabular}{|l|}
49 \\
49.49 \\
\end{tabular} & \begin{tabular}{|l|}
27 \\
27.27 \\
\end{tabular} \\
\hline \multirow{2}{*}{$\begin{array}{l}\text { Kruska1- } \\
\text { Wallis H }\end{array}$} & & & \multicolumn{3}{|c|}{ Chi-Square $=58.548$} & \multicolumn{4}{|c|}{ Chi-Square $=47.494$} & \multicolumn{4}{|c|}{ Chi-Square $=50.055$} \\
\hline & \multicolumn{2}{|c|}{$\mathrm{p}<0.001$} & \multicolumn{3}{|c|}{$\mathrm{p}<0.001$} & \multicolumn{4}{|c|}{$\mathrm{p}<0.001$} & \multicolumn{4}{|c|}{$\mathrm{p}<0.001$} \\
\hline \begin{tabular}{|l|} 
Mann- \\
Whitney U
\end{tabular} & \multicolumn{2}{|c|}{$\begin{array}{l}\text { Mann-Whitney } \\
\mathrm{U}=819.000\end{array}$} & \multicolumn{3}{|c|}{$\begin{array}{l}\text { Mann-Whitney } \\
1,2>0\end{array}$} & \multicolumn{4}{|c|}{ Mann-Whitney U, 3>2>1 } & \multicolumn{4}{|c|}{$\begin{array}{l}\text { Mann-Whitney U } 2>0,1 \text { and } \\
3>0,1\end{array}$} \\
\hline
\end{tabular}

$\mathrm{a}=$ caries free, number of individuals divided by the total number, $97(\mathrm{dmft}, \mathrm{DMFT}=0)$,

$\mathrm{b}=$ with caries, number of individuals divided by the total number, $99(\mathrm{dmft}, \mathrm{DMFT}>0)$

Table 2. Distribution of study participants according to salivary variables and caries status.

tistically significant. Majority (48.48\%) of children with caries belongs to S.mutans level score 3, compared to $10.31 \%$ of caries free children presented with S.mutans level score 3 and the difference was statistically significant (Table 2)

Mean caries score and salivary parameters: Statistically significant difference was seen between S.mutans scores and the mean DMFT,dmft and dmfs scores. Statistically significant difference was seen between mean $\mathrm{dmft}$ and dmfs scores and lactobacilli level. Statistically significant difference was seen between mean DMFT,DMFS, $\mathrm{dmft}$ and $\mathrm{dmfs}$ score and salivary buffering capacity and salivary flow rate (Table 3 ).

Correlations among caries prevalence and salivary fac-

\begin{tabular}{|c|c|c|c|c|c|}
\hline \multicolumn{2}{|l|}{\begin{tabular}{|l|} 
Salivary variables \\
\end{tabular}} & $\mathrm{dmft}$ & $\mathrm{dmfs}$ & DMFT & DMFS \\
\hline \multirow[t]{3}{*}{ Salivary flow rate $(\mathrm{ml} / \mathrm{min})$} & $0(>0.7) \mathrm{n}=175$ & $2.34 \pm 3.425$ & $3.51 \pm 6.017$ & $0.19 \pm 0.632$ & $0.21 \pm 0.724$ \\
\hline & $1(0.3-0.7) n=21$ & $10.33 \pm 3.799$ & $21.43 \pm 11.116$ & $0.57 \pm 1.076$ & $0.57 \pm 1.076$ \\
\hline & & $\mathrm{p}<0.001$ & $\mathrm{p}<0.001$ & $\mathrm{p}<0.05$ & $\mathrm{p}<0.05$ \\
\hline \multirow{3}{*}{ Salivary buffer capacity $(\mathrm{pH})$} & $0(\mathrm{pH}>6) \mathrm{n}=147$ & $1.60 \pm 2.79$ & $2.12 \pm 3.97$ & $0.15 \pm 0.58$ & $0.17 \pm 0.70$ \\
\hline & $1(\mathrm{pH} 4.5-5.5) \mathrm{n}=46$ & $7.72 \pm 4.26$ & $14.20 \pm 10.16$ & $0.43 \pm 0.91$ & $0.43 \pm 0.91$ \\
\hline & $2(\mathrm{pH}<4) \mathrm{n}=3$ & $3.20 \pm 4.25$ & $5.43 \pm 8.70$ & $0.23 \pm 0.69$ & $0.25 \pm 0.77$ \\
\hline \multirow{3}{*}{ ANOVA } & $\mathrm{F}$ & 77.046 & 98.728 & 7.101 & 5.256 \\
\hline & $\mathrm{p}$ & $\mathrm{p}<0.001$ & $\mathrm{p}<0.001$ & $\mathrm{p}=0.001$ & $\mathrm{p}<0.05$ \\
\hline & Tukey's post hoc & $2>1>0$ & $2>1>0$ & $2>0,1>0$ & $2>0$ \\
\hline \multirow[t]{3}{*}{ Salivary S.mutans (CFU/ml ) } & 0 (negligible) $n=3$ & $0.67 \pm 1.15$ & $0.67 \pm 1.15$ & 00 & 00 \\
\hline & $1\left(<10^{4}\right) \mathrm{n}=43$ & $0.74 \pm 2.07$ & $1.14 \pm 3.24$ & $0.05 \pm 0.30$ & $0.05 \pm 0.30$ \\
\hline & $2\left(10^{4}{ }_{1} 10^{5}\right) \mathrm{n}=92$ & $2.24 \pm 3.05$ & $3.14 \pm 4.71$ & $0.18 \pm 0.61$ & $0.21 \pm 0.73$ \\
\hline \multirow{3}{*}{ ANOVA } & $3\left(>10^{5}\right) \mathrm{n}=58$ & $6.67 \pm 5.01$ & $12.50 \pm 11.90$ & $0.47 \pm 0.95$ & $0.48 \pm 1.01$ \\
\hline & $\mathrm{F}$ & 27.603 & 25.731 & 3.553 & 3.034 \\
\hline & $\mathrm{p}$ & $\mathrm{p}<0.001$ & $\mathrm{p}<0.001$ & $\mathrm{p}<0.05$ & $\mathrm{p}<0.05$ \\
\hline & Tukey's post hoc & $3>0,1,2$ & $3>0,1,2$ & $3>1$ & $3>1$ \\
\hline \multirow{3}{*}{$\begin{array}{l}\text { Salivary lactobacilli }(\mathrm{CFU} / \\
\mathrm{ml})\end{array}$} & $0\left(<10^{3}\right) \mathrm{n}=25$ & $0.88 \pm 2.02$ & $1.16 \pm 2.64$ & $0.16 \pm 0.62$ & $0.16 \pm 0.62$ \\
\hline & $1\left(10^{4}\right) n=67$ & $1.36 \pm 2.56$ & $1.94 \pm 4.07$ & $0.09 \pm 0.45$ & $0.12 \pm 0.66$ \\
\hline & $2\left(10^{5}\right) n=74$ & $3.95 \pm 4.05$ & $5.92 \pm 6.63$ & $0.28 \pm 0.76$ & $0.30 \pm 0.82$ \\
\hline \multirow{3}{*}{ ANOVA } & $\begin{array}{l}3\left(>10^{6}\right) n=30 \\
F\end{array}$ & $\begin{array}{l}7.40 \pm 5.44 \\
22.991\end{array}$ & $\begin{array}{l}15.60 \pm 14.28 \\
27.043\end{array}$ & $\begin{array}{l}0.50 \pm 0.93 \\
2.691\end{array}$ & $\begin{array}{l}0.50 \pm 0.93 \\
1.911\end{array}$ \\
\hline & $\mathrm{p}$ & $\mathrm{p}<0.001$ & $\mathrm{p}<0.001$ & $\mathrm{p}<0.05$ & $p=0.23$ \\
\hline & Tukey's post hoc & $3>2>0,3>2>1$ & $3>2>0,3>2>1$ & $3>1$ & NS \\
\hline
\end{tabular}

NS = not significant

Table 3. Distribution Of Study Participants with Mean dmft, dmfs, DMFT and DMFS scores according To Salivary variables. 


\begin{tabular}{|l|l|l|l|l|}
\hline \multirow{2}{*}{ Variable } & \multicolumn{4}{|l|}{ Correlation coefficients } \\
\cline { 2 - 5 } & $\mathrm{dmft}$ & $\mathrm{dmfs}$ & DMFT & DMFS \\
\hline Salivary flow rate & $0.489^{\mathrm{a}}$ & $0.513^{\mathrm{a}}$ & $0.167^{\mathrm{b}}$ & $0.166^{\mathrm{b}}$ \\
\hline $\begin{array}{l}\text { Salivary buffering } \\
\text { capacity }\end{array}$ & $0.645^{\mathrm{a}}$ & $0.670^{\mathrm{a}}$ & $0.286^{\mathrm{a}}$ & $0.285^{\mathrm{a}}$ \\
\hline $\begin{array}{l}\text { Salivary S.mutans } \\
\text { level }\end{array}$ & $0.536^{\mathrm{a}}$ & $0.539^{\mathrm{a}}$ & $0.243^{\mathrm{a}}$ & $0.243^{\mathrm{a}}$ \\
\hline $\begin{array}{l}\text { Salivary lactoba- } \\
\text { cilli }\end{array}$ & $0.515^{\mathrm{a}}$ & $0.525^{\mathrm{a}}$ & $0.211^{\mathrm{a}}$ & $0.211^{\mathrm{a}}$ \\
\hline
\end{tabular}

$\mathrm{a}=$ Correlation is significant at the 0.01 level,

$\mathrm{b}=$ Correlation is significant at the 0.05 level.

Table 4. Correlations of dmft, dmfs, DMFT, and DMFS to salivary findings.

tors: Table 4 shows the correlation coefficients of mean dmft, dmfs, DMFT and DMFS values with salivary findings in the total sample. All the variables showed highly significant $(\mathrm{p}<0.001)$ correlation with both $\mathrm{dmft}$ and dmfs values.

\section{Discussion}

This study is a part of ongoing longitudinal study, with aim to assess the possible relationship between salivary cariogenic microflora, buffer capacity, secretion rate and caries experience among 6 year old school going children. The result showed, out of 196 study participants, $99(50.51 \%)$ children presented with caries (dft,DMFT $>0)$, out of which $42(42.42 \%)$ were boys and $57(57.58 \%)$ were girls and there was no significant difference between two groups. The mean dmft and dmfs score was 3.23 and 5.43 and mean DMFT and DMFS score was 0.23 and 0.25 respectively. The study conducted by Gamboa $\mathrm{F}$ et al showed over all caries prevalence of $66 \%$ (35/53) among 3-5 year old children in Colombia, which was slightly higher compared to present study results (15). The study conducted by Alaluusua S among 5 year old children in Helsinki, showed $38.25 \%$ of children presented with caries and mean dmfs for overall group was 2.2, which was lower compared to present study results (16). In the present study a total of $98.47 \%$ carried detectable salivary levels of S.mutans and $46.94 \%$ of these belonged to S.mutans score $2\left(10^{4}\right.$ $\left.-10^{5} \mathrm{CFU} / \mathrm{ml}\right)$ and $29.59 \%$ with score $3\left(>10^{5} \mathrm{CFU} / \mathrm{ml}\right)$ and a total of $87.24 \%$ carried detectable salivary levels of lactobacilli and $37.75 \%$ of these belonged to score $2\left(10^{5} \mathrm{CFU} / \mathrm{ml}\right)$. Statistically significant difference was seen between mean caries score and salivary S.mutans count and lactobacillus. In contrast to this, the study conducted by Gamboa F et al showed only $62 \%$ of study participants presented with positive salivary S.mutans and there was no statistically significant difference between S.mutans count and dental caries experience (15). The study conducted by Alaluusua S et al showed 54\% of the saliva samples not detected S.mutans, only 6\% of children showed high salivary level of S.mutans and statistically significant difference was seen between salivary S.mutans levels and mean caries score (16). The study conducted by Bretz WA et al among 3-6 year old children from Brazil, showed $70 \%$ and $46 \%$ of the children had moderate to high salivary levels of mutans streptococci and lactobacilli respectively and high correlation was seen between salivary levels of S.mutans and lactobacilli and dental caries prevalence (17). This results tallies with the present study result, which showed highly significant correlation between salivary microflora and mean caries score.

A lot of research has been done to find out and prove the influence of salivary S.mutans and lactobacillus on caries experience in children and adult population $(3,5-8$, $18-20,27)$. Our results also showed statistically significant relation between different levels of S.mutans and lactobacilli and caries experience. The study conducted by Campus $\mathrm{G}$ et al showed similar results (8). Although high levels of S.mutans and lactobacilli indicate a cariogenic environment, many authors (21-22) believe that this may be partly due to different microbiological sampling methods (stimulated or non-stimulated saliva, plaque or total saliva). In addition, the type of research study may also influence the correlation between streptococci levels and disease. However, the study in 2002 by Dasanayake AP., et al, using "Dentocult MS" (Orion diagnostic, Finland) set, among children of 2-17 year old Srilankan children and study conducted by Gudkina $\mathrm{J}$ among 6 and 12 year old in Riga found no positive correlation between caries and salivary S.mutans level $(23,24)$.

Present study showed, salivary secretion rate for overall sample was between $0.4-1.5 \mathrm{ml} / \mathrm{min}$ with a mean flow rate of $0.96 \pm 0.23 \mathrm{ml} / \mathrm{min}$. The analysis of the buffer capacity of saliva showed that the majority $(75 \%)$ of participants present with buffer capacity of $>6 \mathrm{pH}$, followed by $23.47 \%$ with buffer score of $1(\mathrm{pH} 4.5-5.5)$. Highly significant $(\mathrm{p}<0.01)$ correlation was seen between mean caries score and salivary buffer capacity and flow rate. This result is in contrast to the study conducted previously $(25,26)$ and, which showed no significant difference between salivary $\mathrm{pH}$ and salivary flow rate and mean caries score.

Comparison of all results with other studies was not possible, as disparity between results exist. This could be attributed to difference in $\mathrm{dmft}$ values, dietary pattern, oral hygiene practice, genetic factors and several other factors peculiar to the study population. Also distinctness in the technique of sampling saliva and cultivation of bacteria can contribute to variation.

To conclude, high levels of salivary microbiological counts in correlation with the caries data stress the importance of these factors and urge the necessity of elective preventive programs in this region and this study can serve as a basis to develop a caries prediction model 
using other variables such as oral hygiene status, dietary factors, sociodemographic details etc in the future.

\section{References}

1. Loesche W. Role of streptococcus mutans in human dental decay. Microbiol Rev. 1986;50:353-80.

2. Petersen PE, Bourgeois D, Ogawa H, Estupinan -Day S, Ndiaye C. The global burden of oral diseases and risks to oral health. Bull World Health Organ. 2005;83: 661-9.

3. Hegde PP, Ashok Kumar BR, Ankola VA. Dental caries experience and salivary levels of streptococcus mutans and lactobacilli in 13-15 years old children of Belgaum city,Karrnataka. J Indian Soc Pedod Prev Dent. 2005;23:23-6.

4. Das UM, Beena JP, Azher U. Oral health status of 6- and 12 -year -old school going children in Bangalore city: an epidemiological study. J Indian Soc Pedod Prev Dent. 2009;27:6-8.

5. Beighton D, Adamson A, Rugg-Gunn A. Associations between dietary intake, dental caries experience and salivary bacterial levels in 12- year -old English school children. Arch Oral Biol. 1996;41:271-80.

6. Zoitopoulos L, Brailsford SR, Gelbier S, Ludford RW, Marchant $\mathrm{SH}$, Beighton D. Dental caries and caries-associated micro-organisms in the saliva and plaque of 3- and 4- year- old Afro-Caribbean and Caucasian children in south London. Arch Oral Biol. 1996;41:1011-8.

7. del Rio Gomez I. Dental caries and mutans streptococci in selected groups of urban and native Indian Schoolchildren in Mexico. Community Dent Oral Epidemiol. 1991;19:98-100.

8. Campus G, Lumbau A, Bachisio SL. Caries experience and streptococci and lactobacilli salivary levels in 6-8-year-old Sardinians. Int J Paediatr Dent. 2000;10:306-12.

9. Bader JD, Graves RC, Disney JA, Bohannan HM, Stamm JW, Abernathy JR, Lindahl RL. Identifying children who will experience high caries increments. Community Dent Oral Epidemiol. 1986;14:198-201.

10. Leverett DH, Featherstone JD, Proskin HM, Adair SM, Eisenberg AD, Mundorff-Shrestha SA et al. Caries risk assessment by a crosssectional discrimination model. J Dent Res. 1993 ;72:529-37.

11. Raitio M, Pienihakkinen K, Scheinin A. Assessment of single risk indicators to caries increment in adolescents. Acta Odontol Scand. 1996;54:113-117.

12. Alaluusua S, Kleemola-Kujala E, Nystrom M, Evalahti M, Grönroos L. Caries in primary teeth and salivary streptococcus mutans and lactobacillus levels as indicators of caries in permanent teeth. Paediatr Dent. 1987;9(2):126-30.

13. Vanobbergen J, Martens L, Lesaffre E, Bogaerts K, Declerck D. Assessing risk indicators for dental caries in the primary dentition. Community Dent Oral Epidemiol. 2001;29:424-34.

14. Braga MM, Oliveira LB, Bonini GA, Bonecker M, Mendes FM. Feasibility of the International Caries Detection and Assessment System (ICDAS-II) in epidemiological surveys and comparability with standard World Health Organization criteria. Caries Res. 2009;43:245-9.

15. Gamboa F, Estupinan M, Chaves M, Galindo A. Bacteriocins in S. mutans strains isolated from children with and without dental caries: biotypes and sensitivity to antibiotics. Acta Odontol Latinoam.2008;21:97-104.

16. Alaluusua S, Myllarniemi S, Kallio M. Streptococcus mutans infection level and caries in a group of 5 year old children. Caries Res. 1989;23:190-4.

17. Brezt WA, Djahjah C, Almeida RS, Hujoel PP, Loesche WJ. Relationship of microbial and salivary parameters with dental caries in Brazilian pre-school children. Community Dent Oral Epidemiol. 1992;20:261-4.

18. van Houte J. Microbiological predictors of caries risk. Adv Dent Res. 1993;7:87-96.Review.

19. Twetman S, Stahl B, Nederfors T. Use of the strip mutans tests in the assessment of caries risk in a group of preschool children. Int $\mathrm{J}$
Paediatr Dent. 1994;4:245-50.

20. Raitio M, Pienihakkinen K, Scheinin A. Assessment of single risk indicators in relation to caries increment in adolescents. Acta Odontal Scand. 1996;54:113-7.

21. Alaluusua S. Salivary counts of mutans streptococci and lactobacilli and past caries experience in caries prediction. Caries Res. 1993;27:68-71.

22. Shi S, Zhao Y, Hayashi Y, Yakushiji M, Machida Y. A study of the relationship between caries activity and the status of dental caries: application of the Dentocult LB method. Chin J Dent Res. 1999;2:34-7.

23. Dasanayake AP, Caufield PW. Prevalence of dental caries in Sri Lankan aboriginal Veddha children. Int Dent J. 2002;52:438- 44.

24. Gudkina J, Brinkmane A. Caries experience in relation to oral hygiene, salivary cariogenic microflora, buffer capacity and secretion rate in 6- year olds and 12 year olds in Riga. Stomatologija. 2008;10:76-80.

25. Sullivan A. Correlation between caries incidence and secretion rate/buffer capacity of stimulated whole saliva in 5-7-year-old children matched for lactobacillus count and gingival state. Swed Dent J. 1990;14:131-5.

26. Russell JI, MacFarlane TW, Aitchison TC, Stephen KW, Burchell CK. Caries prevalence and microbiological and salivary caries activity tests in Scottish adolescents. Community Dent Oral Epidemiol. 1990;18:120-5.

27. Ruiz Miravet A, Montiel Company JM, Almerich Silla JM. Evaluation of caries risk in a young adult population. Med Oral Patol Oral Cir Bucal. 2007;12:412-8. 